UDC 628:81

DOI: $10.30929 / 2072-2052.2018 .4 .44 .53-59$

\title{
COMPREHENSIVE MODEL OF AUTOMATED CONTROL SYSTEM OF HEATING IN MULTI-STOREY BUILDING
}

\section{A. Perekrest, V. Chenchevoi, Ye. Chebotarova}

Kremenchuk Mykhailo Ostrohradskyi National University

vul. Pershotravneva, 20, Kremenchuk, 39600, Ukraine.

E-mail:pksg13@gmail.com, vladchen.86@gmail.com,yevheniia.ch93@gmail.com

Purpose. To create a comprehensive model that describes the functioning of the control system in the district heating substation. Methodology. We have applied the passive multifactorial experiment with regression analysis for finding the dependence of the internal temperature in the rooms on the temperature of the coolant return pipe, the thermal power of the heating system and the ambient temperature. Results. We have developed the mathematical model, which describes the function of the control system in district heating substation. The adequacy of the model is verified with Pearson's correlation coefficient, the coefficient of determination, the adjusted coefficient of determination, the standard error of the regression equation, Student's coefficient. Quality indicators have confirmed that the model has high relevance. Analysis of the mathematical model and response surfaces prove the correctness of the description of physical processes. Statements based on the analysis of the model can confirm this. The outdoor temperature significantly influences the value of the internal temperature in the premises. Since its value determines the operating mode of the heating system. The lower the temperature of the coolant return pipeline and the higher the thermal power, the lower the temperature inside the room. Originality. We have carried out the research of control system of the district heating substation in the conditions of the existing heating process. Practical value. The obtained results can be used to optimize the work of control system of the district heating substation in multi-storey buildings. The model is allowed to find optimal values of the temperatures of the return coolant pipeline, which provide guaranteed heat energy savings. References 11, tables 3, figures 8.

Key words: centralized heating, regression analysis, passive multi-factor experiment.

\section{КОМПЛЕКСНА МОДЕЛЬ АВТОМАТИЗОВАНОЇ СИСТЕМИ КЕРУВАННЯ ТЕПЛОСПОЖИВАННЯМ БАГАТОКВАРТИРНОГО БУДИНКУ}

\section{А. Л. Перекрест, В. В. Ченчевой, С. О. Чеботарьова}

Кременчуцький національний університет імені Михайла Остроградського

вул. Першотравнева, 20, м. Кременчук, 39600, Україна.

E-mail:pksg13@gmail.com, vladchen.86@gmail.com,yevheniia.ch93@gmail.com

Проведено пасивний багатофакторний експеримент з використанням регресійного аналізу для визначення залежності значення внутрішньої температури у представницькому приміщенні багатоквартирного будинку від температури теплоносія у зворотньому трубопроводі, теплової потужності системи опалення та температури навколишнього середовища. Отримано математичну модель, що комплексно описує роботу системи керування тепловим пунктом. Перевірка адекватності моделі проведена за допомогою коефіцієнта кореляції Пірсона, коефіцієнта детермінації, скоригованого коефіцієнта детермінації, стандартної помилки рівняння регресії, коефіцієнта Стьюдента. Показники якості підтвердили високу адекватність отриманої моделі. Отримані результати можуть використовуватись для налаштувань роботи автоматизованих індивідуальних теплових пунктів багатоповерхових житлових будинків у вигляді рекомендацій до значень зворотних температур теплоносія, що забезпечують гарантовану економію теплової енергії при підтримці нормативних внутрішніх температур.

Ключові слова: тепловий пункт, регресійний аналіз, пасивний багатофакторний експеримент.

PROBLEM STATEMENT. With rising prices for imported energy resources, the question of energy independence of our country is very acute. The largest amount of energy resources is consumed by the housing and utilities sector to meet heating, hot water supply and ventilation needs. This is due to the use of central heating points (CHPs), which operate on outdated temperature graphs of cities, which leads to overheating in the warm period, and inappropriate in cold. In addition, the large length of the pipelines network, which connects CHP with separate buildings, leads to significant losses of heat energy during transportation.

Taking into account the above, there is a need for modernization of elements of the central heating system. At the same time, at the first stage, it is necessary to reduce heat consumption of end consumers by introduction of individual heat points (ITP). The advantage of this solution is not only the possibility of saving heat energy by automatically adjusting of the heat flow coming from the heating network, depending on the temperature of the outside air, but also providing a comfortable temperature inside the premises.

It is possible to increase ITP efficiency by optimizing the algorithms of control of the operating mechanisms of automated units of heat input.

The purpose of this work is creation of a mathematical model that would comprehensively describe the link of input effects, state parameters and output signals of an automated system for monitoring and controlling the heat consumption in multi-storey 
building.

EXPERIMENTAL PART AND RESULTS OBTAINED. The analysis of works [1-5] suggests that for the purposes of identification and creation of mathematical models of technological objects of control (TOC), two approaches are used: physics and mathematical analysis of phenomena and experimental identification of TOC. In most cases, physicalmathematical analysis is ineffective, in contrast to experimental methods that can use a priori information about the object parameters.

Experimental methods include active and passive experiment. Active experiment involves the possibility of influencing the object during its carrying out. The mathematical model obtained as a result of this type of experiment is a set of static and dynamic output characteristics, which are recorded perturbation action at input to the object. Passive experiment is carried out when registering input and output parameters of the object without interference during its carrying out. The experiment involves the use of mathematical and statistical methods only for the processing of collected experimental data.

As the heat point must provide given temperature schedule, it is impossible to conduct active experiment in these conditions. Therefore, passive experiment was chosen to study the heat point control system.

It was selected the heat node (Fig. 1) of multiapartment residential building of apartment building coowners association (ABCA) of the city Kremenchuk as a research object. Before the start of heating season 2017/2018 under the terms of "Warm Credit" program, the heat input node was upgraded. Financial liabilities of ABCA in the amount of 240 thousand $\mathrm{UAH}$ were distributed as follows: 120 thousand UAH is nonrepayable assistance of state authorities; 80 thousand UAH is credit funds; 40 thousand UAH is own funds of ABCA. As a result of heat input modernization, it was installed the automated system for monitoring and controlling of heat consumption (ASMC) with special software (Ascontrol) [6, 7].

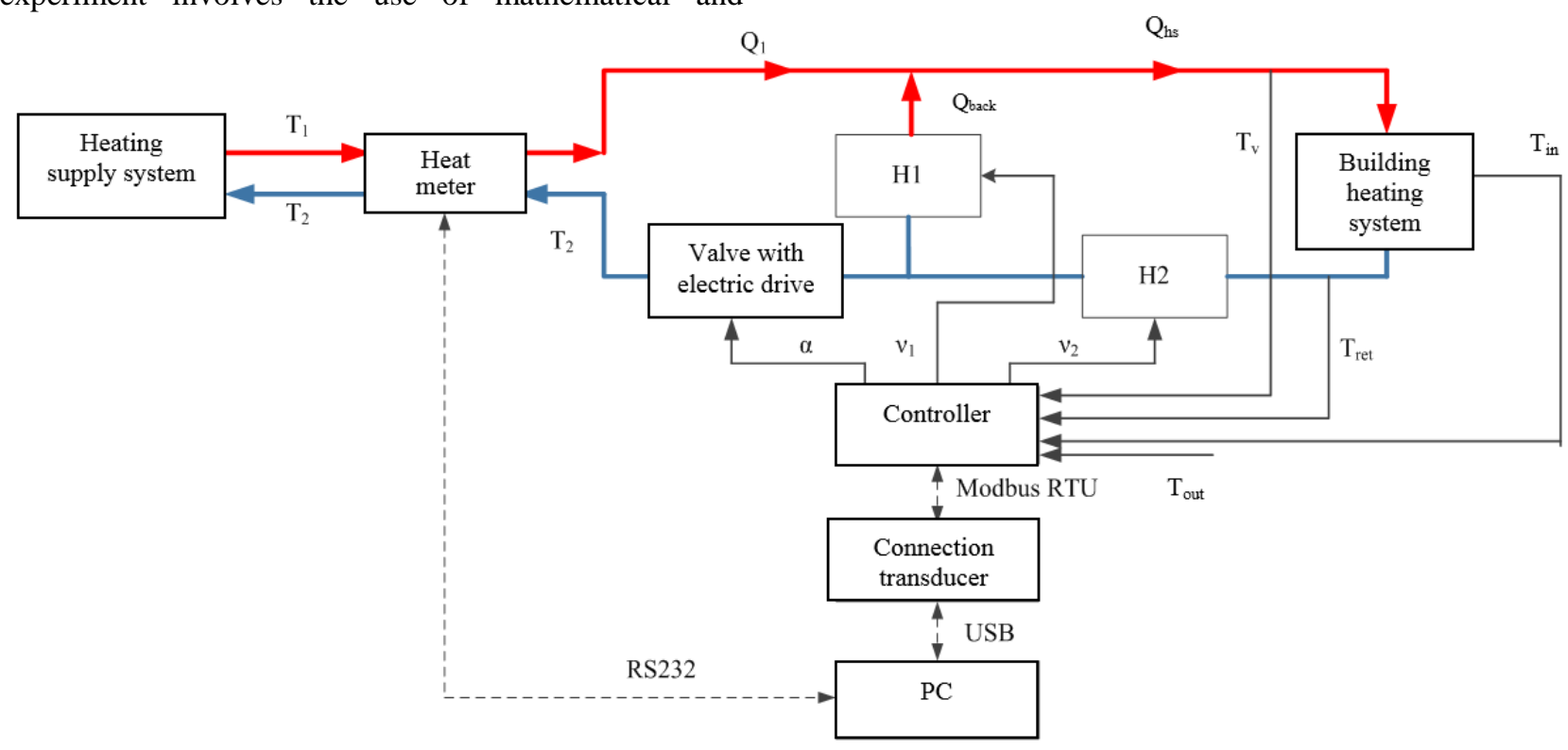

Figure 1 - Modernized heat node of a dwelling house

The local ASMC level of heat consumption includes subsystems based on measuring, operating and adjusting elements that perform the task of collecting and processing signals about the state of heat consumption, and in the automated mode, change the heat power according the weather-dependent algorithm. In this case, a heat meter with temperature sensors and heat carrier consumption for measuring of the heat power consumption is used; automated node of weatherdependent adjusting on the basis of the regulator, valve with electric drive, pump and temperature sensors of the heat carrier, internal and external air. The heat meter and regulator via industrial interfaces are connected with personal computer (PC) with Windows operating system, on which has installed local software that provides temperature control of the heat carrier, air inside and outside the room; change the settings and settings of the regulator, save information about the operation of the heat point in the file and the local database [6].

The basic indicators of heat energy consumption were taken the value of 2016/2017 (859 Gcal) and average seasonal heat consumption for 2014-2017 (964 Gcal). The cost of 1 Gcal of heat energy in $2016 / 2017$ and $2017 / 2018$ was 1160.15 UAH for ABCA.

The implementation of ASMC made it possible to reduce seasonal heat consumption in 2017/2018 to 675 Gcal that is $27.2 \%$, compared with 2016/2017 and $29.9 \%$ against the average seasonal heat consumption in 2014-2017.

Savings from ASMC using made up $183.9 \mathrm{Gcal}$ and 213.3 thousand UAH, as compared with 2016/2017 heating season and $289 \mathrm{Gcal}$ and 335 thousand $\mathrm{UAH}$, as compared to average for the three previous heating seasons (before the modernization) (Fig. 2). 


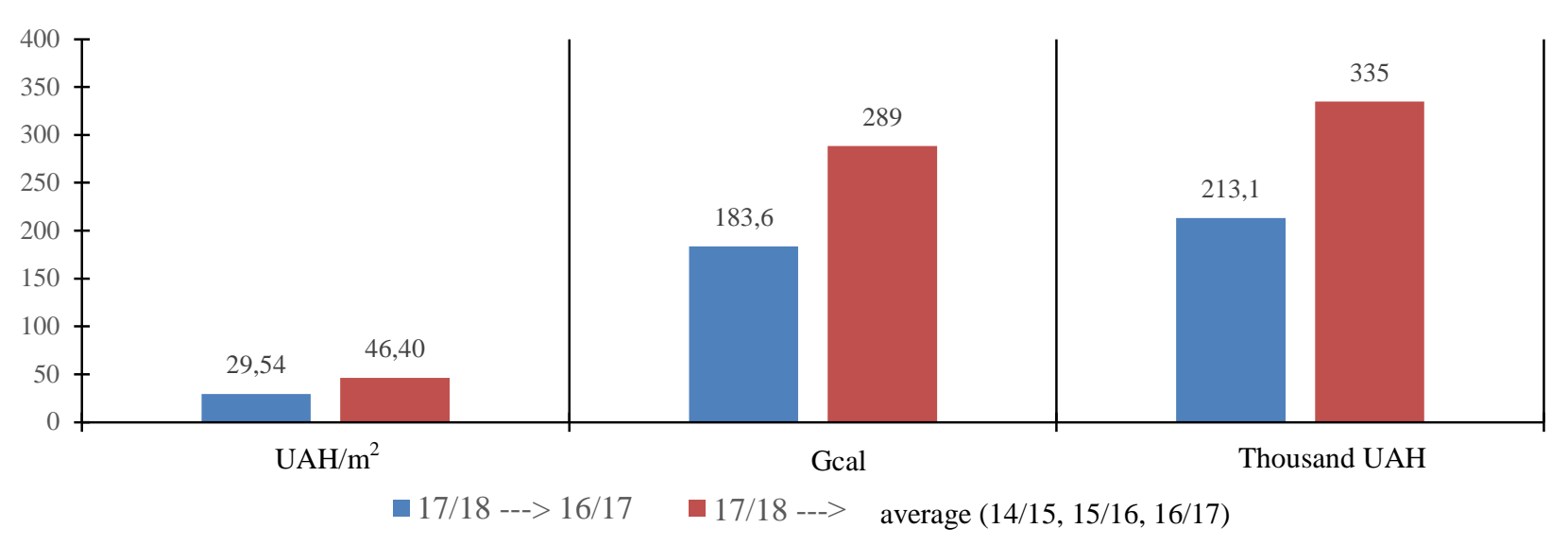

Figure 2 - Heat energy savings from ASMC using by heat consumption

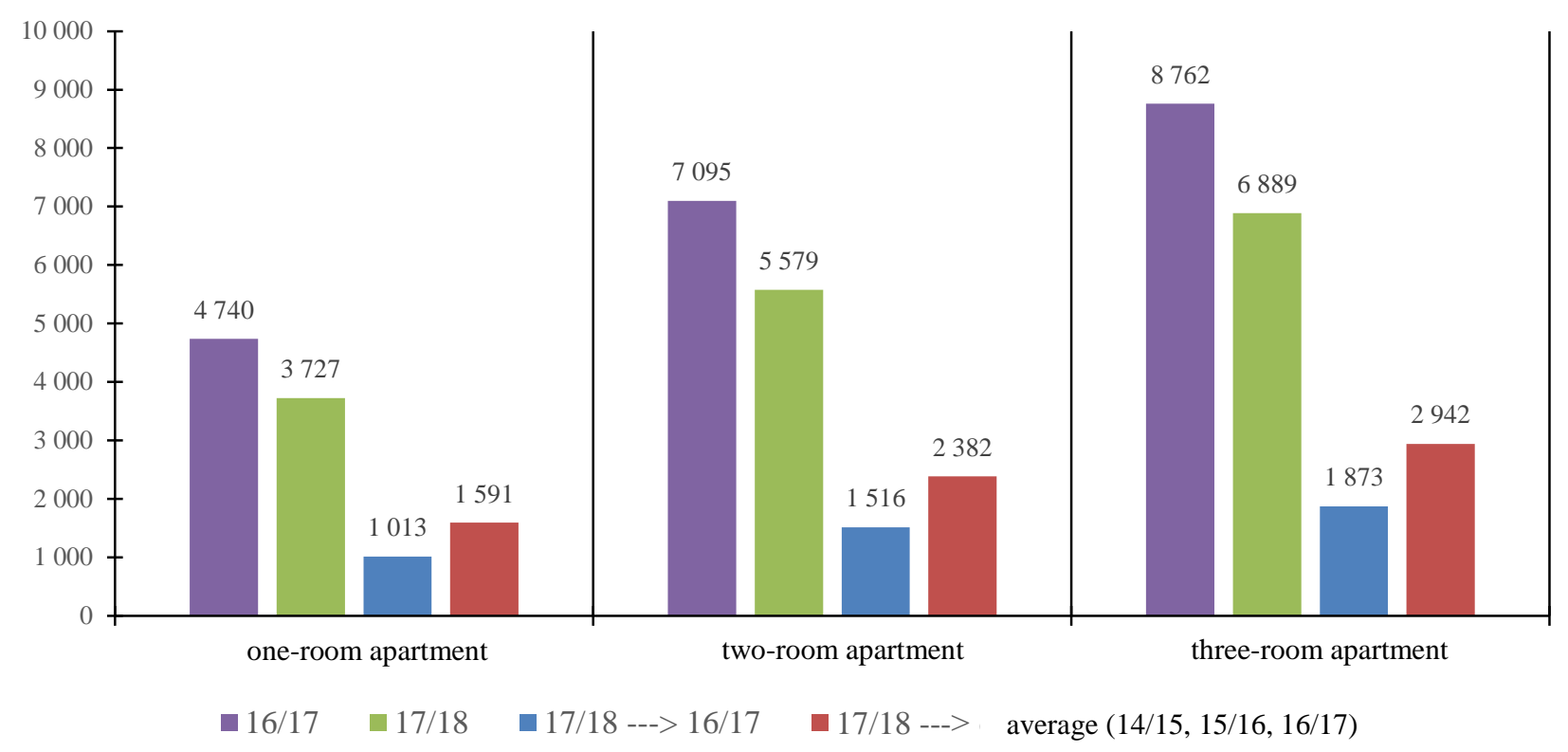

Figure 3 - Seasonal expenses and saving of apartments for payment for heating, UAH

In addition, seasonal expenses of apartments for heating services decreased significantly by $29.57 \mathrm{UAH}$ per $1 \mathrm{~m}^{2}$ against 2016/2017 and 46.44 UAH per $1 \mathrm{~m}^{2}$, as compared with average for the three preceding heating seasons upgrading (Fig. 3). The size of savings (46.44 $\mathrm{UAH} / \mathrm{m}^{2}$ and 335 thousand $\mathrm{UAH}$ ) is determined at the cost of $1 \mathrm{Gcal}$ of heat energy of $1160.15 \mathrm{UAH}$.

Measurements were made using monitoring devices connected to the Internet, with the ability to record, store, view and download the value archive.

The data set for the model creation is received on the basis of ASMC results by heat consumption (Fig. 4) and includes the parameters: Data - date, Time - time, $T_{v}-$ heat carrier temperature at the input to the heating system, $T_{r e t}-$ heat carrier temperature in the return pipeline of the heating system, $T_{1_{-} t g}-$ heat carrier temperature of at the input to the house according to the temperature schedule, $T_{v_{-} t g}$ - heat carrier temperature in the input to the heating system according to the temperature schedule, $T_{\text {ret_tg }}$ - heat carrier temperature in the return pipeline of the heating system according to the temperature schedule, $T_{\text {in }}$ - inside temperature in the premises of the building, $T_{\text {out }}-$ external air temperature.

The construction of complex mathematical models deprives the system of flexibility and universality and requires the use of high-speed hardware for modeling. Therefore, the most influential of the total set of parameters was chosen: $T_{r e t}$ is the temperature of the heat carrier in the return pipeline of the heating system, $T_{\text {in }}$ is the temperature inside the premises, $T_{\text {out }}$ is the temperature of outside air (Fig. 5). 


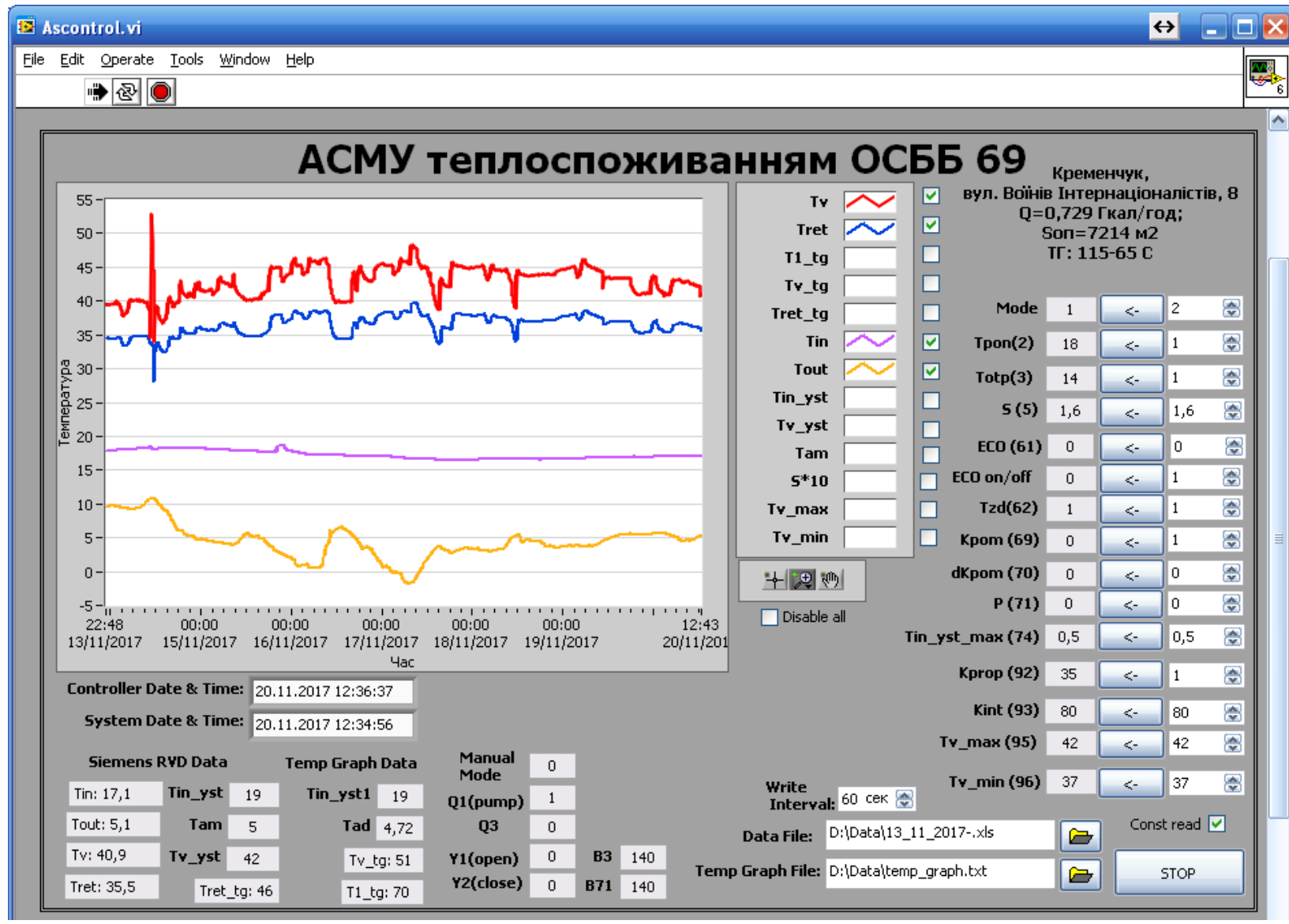

Figure 4 - ASMC user interface by heat consumption of ABCA

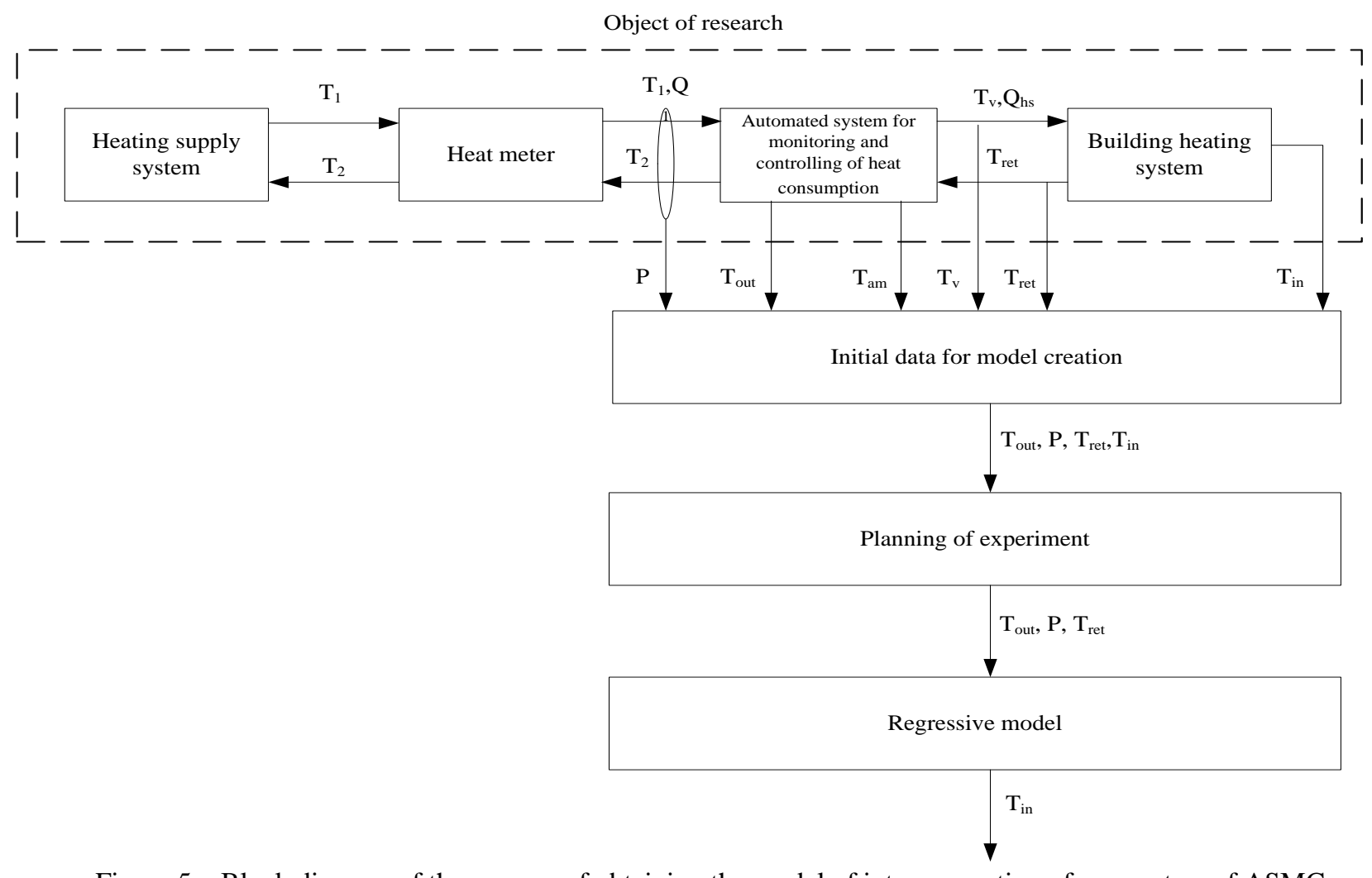

Figure 5 - Block diagram of the process of obtaining the model of interconnection of parameters of ASMC 
In order to solve the problem of the research work of the control system of heat point of a residential building in the conditions of existing heating process, it is reasonably to obtain a static model (regression equation) in a passive experiment using the regression analysis method [8-9].

The data obtained during the work of ASMC were 16 tests of experiments (Tabl. 1).

Table 1 - Input data

\begin{tabular}{|c|c|c|c|c|c|}
\hline Date & $\begin{array}{c}T_{\text {out }}, \\
{ }^{\circ} \mathrm{C}\end{array}$ & $\begin{array}{c}P, \\
\text { Gcal } \\
\text { /hour }\end{array}$ & $\begin{array}{c}T_{\text {ret }}, \\
{ }^{\circ} \mathrm{C}\end{array}$ & $T_{\text {in }},{ }^{\circ} \mathrm{C}$ & $T_{v},{ }^{\circ} \mathrm{C}$ \\
\hline 21.10 .17 & 8.1 & 0.131 & 36.6 & 19 & 42.6 \\
\hline 23.10 .17 & 5.6 & 0.126 & 35.8 & 18.4 & 41.5 \\
\hline 24.10 .17 & 5.3 & 0.137 & 35.8 & 18.4 & 41.7 \\
\hline 27.10 .17 & 5.15 & 0.134 & 36 & 17.2 & 40.8 \\
\hline 29.10 .17 & 5.11 & 0.115 & 35.4 & 17.1 & 42 \\
\hline 03.11 .17 & 0.5 & 0.19 & 39 & 15.5 & 47 \\
\hline 07.11 .17 & 4 & 0.149 & 38.6 & 17.3 & 43.4 \\
\hline 09.11 .17 & 0.3 & 0.172 & 40.8 & 17 & 46.2 \\
\hline 20.11 .17 & -0.14 & 0.205 & 42.2 & 16.4 & 48.6 \\
\hline 20.11 .17 & 3.7 & 0.117 & 38 & 17 & 43 \\
\hline 25.11 .17 & -1.8 & 0.163 & 42.7 & 15.8 & 48.7 \\
\hline 09.12 .17 & -7.4 & 0.223 & 41 & 13.2 & 49 \\
\hline 19.12 .17 & 3 & 0.167 & 38.3 & 15.8 & 44.3 \\
\hline 21.12 .17 & -0.5 & 0.184 & 39.3 & 15.2 & 46 \\
\hline 31.12 .17 & -0.5 & 0.146 & 37 & 15.7 & 42.3 \\
\hline 21.01 .18 & -1.7 & 0.173 & 39.3 & 15.6 & 45.6 \\
\hline
\end{tabular}

The internal air temperature sensor is in a nonheated room - there is a significant decrease in $T_{i n}$ when $T_{\text {out }}$ reduced. At the same time, according to the results of additional every-minute measurements of the temperature values and humidity of internal air in separate apartments of the lower floors of two entrances, it was established that the temperatures fluctuated within $20-23{ }^{\circ} \mathrm{C}$, and the humidity fluctuation was $32-38 \%$.

Measurements were made using monitoring devices connected to the Internet with the ability to record, store, view and download an archive of values [10].

It was carried out passive multifactorial experiment with using of software package of statistical analysis Statgraphics to determine the dependence of the internal temperature values in the premises on the temperature of the heat carrier in the return pipline, the heat power of the heating system and the temperature of the environment. The task of regression analysis is that, based on available output data (value of recall and input factors), as accurately as possible, evaluate the values of unknown parameters of the regression equation.

Based on the data of the multi-factor experiment, the following regression equation was obtained:

$$
\begin{aligned}
T_{\text {in }}=10.4871 & +0.366673 T_{\text {out }}-7.76245 P+ \\
& +0.17202 T_{\text {ret }}
\end{aligned}
$$

The evaluation of the obtained dependence quality was made by checking of the conditions performance of the accuracy coefficients [11]:
- Pearson correlation coefficient:

$$
R=\frac{\sum(x-\bar{x})(y-\bar{y})}{\sqrt{\sum(x-\bar{x})^{2}(y-\bar{y})^{2}}}>0.7,
$$

where $x, y$-data files;

- coefficient of determination $\mathrm{R}^{2}>0.5$;

- coefficient of adjusted coefficient of determination:

$$
R_{a d j}^{2}=1-\left(1-R^{2}\right) \frac{n-1}{n-p-1}>0.5,
$$

where $n$ - number of observations, $p$ - number of input variables;

- standard error of the regression equation:

$$
S E=x_{\text {max }}-x_{\text {min }}<0.3,
$$

and coefficients of reliability of the regression model:

- Student's coefficient $t_{s}>2$;

- P-value $p<0.5$.

Quality indicators confirmed the high adequacy of the obtained equation (Tabl. 2).

Table 2 - Regressive statistics

\begin{tabular}{|l|c|}
\hline Pearson's correlation coefficient $R$ & 0.93205 \\
\hline Coefficient of determination $R^{2}$ & 0.868716 \\
\hline $\begin{array}{l}\text { Adjusted coefficient of determination } \\
R^{2}\end{array}$ & 0.835895 \\
\hline Standard error & 0.586647 \\
\hline
\end{tabular}

On the basis of the obtained regression equation, the response surface of output parameter is constructed the value of internal temperature in the premises (Fig. 6, 7).

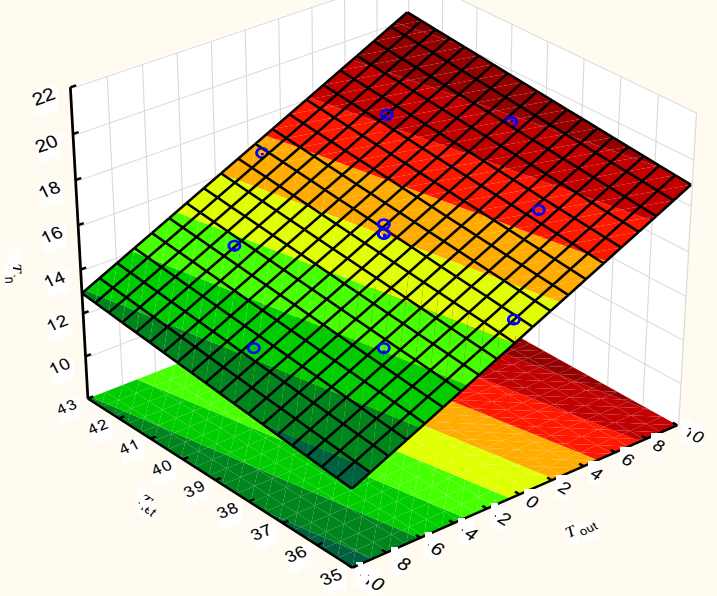

Figure 6-Dependence of the temperature inside the premises on the temperature of the heat carrier in the return pipeline of the heating system and outside temperature

Analysis of the parameters of regression equation (Tabl. 3) and response surfaces (Fig. 6, 7) showed that internal air temperature is significantly influenced by the external air temperature as its value determines the operating mode of the heating system. 


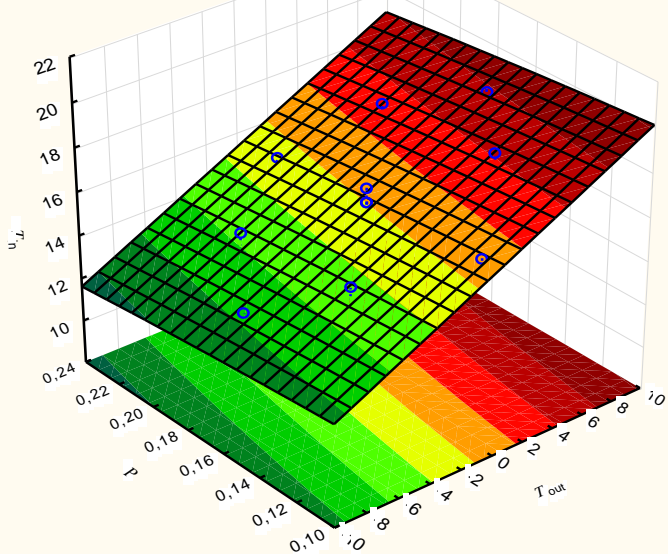

Figure 7 - Dependence of temperature value in premises from the heat power of the heating system and outside temperature

Table 3 - Parameters of regression equation

\begin{tabular}{|c|c|c|}
\hline Change & t-statistics & $P$-value \\
\hline Y-intersection & 2.691938 & 0.019599 \\
\hline$T_{\text {out }}$ & 5.058014577 & 0.00028074 \\
\hline$P$ & -0.836796406 & 0.41905976 \\
\hline$T_{\text {ret }}$ & 1.57748356 & 0.14066812 \\
\hline
\end{tabular}

The lower the temperature of the heat carrier in the return pipeline and the higher the heat power, the lower the temperature inside the premises.

Consequently, we can conclude that the regression model obtained adequately describes the physical processes that occur during the operation of the control system of the heat point.

The analysis of adequacy is based on analysis of residuals. To do this we will use the visual method (Fig. 8), the analysis of which shows that the residuals are disorder scattered on the plane and in their behavior are not regularities.

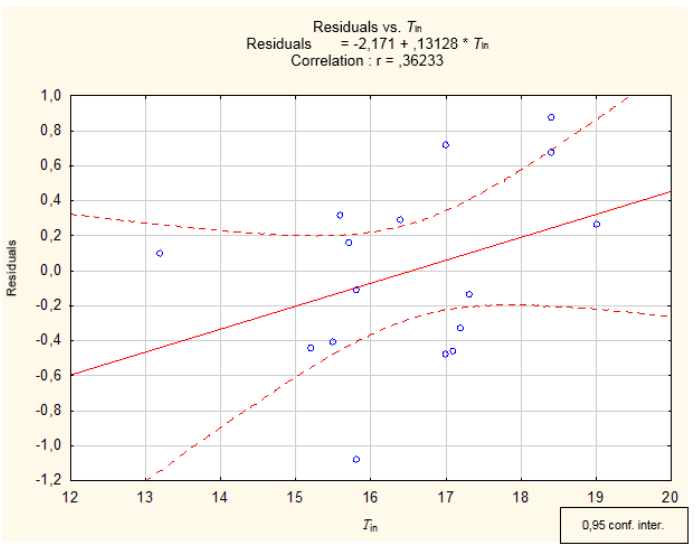

Рисунок 8 - Analysis of the residuals of mathematical model

CONCLUSION. In this work, a comprehensive model was obtained that describes with high confidence the work of the ASMK by the heat consumption of an apartment building. The results can be used to customize the operation of automated ITPs in multistorey buildings as recommendations to the values of the return temperature of the heat carrier $T_{\text {ret }}$, which provide guaranteed savings of thermal energy with the support of standard internal temperatures.

\section{REFERENCE}

1. Avetisyan, A.R., Pashchenko, A.F. and Pashchenko, F.F. (2013), Teplogidravlicheskie modeli oborudovaniya elektricheskih [Thermal-hydraulic models of power plants equipment], Fizmatlit, Moscow. (in Russian)

2. Berezhny, S.V. and Melnik, O.Ye. (2012), "Methods of determination of specific norms of power consumption", Zbirnyk naukovykh prats Kirovohradskoho natsionalnoho tekhnichnoho universytetu "Tekhnika v silskohospodarskomu vyrobnytstvi, haluzeve mashynobuduvannia, avtomatyzatsiia", Iss. 25 , no. 2, pp. 145-150. (in Ukrainian)

3. Perekrest, A.L. and Karaybida, T.V. (2014), "Identification processes in heating systems educational buildings", Visnyk KrNU: Naukovi pratsi KrNU, Vol. 2, no. 82, pp. 35-42. (in Russian)

4. Osadchy, S.I., Vikhrova, L.G., Didik, O.K. and Zozulya, V.A. (2017), "Identification of a multidimensional object in a closed-loop control system based on data from a passive experiment", Intelektualni systemy pryiniattia rishen ta problemy obchysliuvalnoho intelektu. Materialy mizhnarodnoi konferentsii [Intellectual systems for decision making and problems of computational intelligence. Conference proceedings], Zaliznyi Port, May 22-26, 2017, pp. 127-129. (in Ukrainian)

5. Basok, B.I. (2014), "Features of heating the administrative building on the basis of an individual heating point", Budivelni konstruktsii, Vol. 80, pp. 95-98. (in Ukrainian)

6. Zagirnyak, M.V. and Perekrest, A.L. (2014), "Experience implementing and using the automated system temperature monitoring and remote control of the heat load of the Kremenchug national university", Elektrotehnicheskie $i$ kompyuternie sistemy, no. 91, pp. 423-426. (in Russian)

7. Kush-Zhirko, M.O. and Perekrest, A.L. (2018), A.S. Ukraine no. 81033 Software product "Programming of an automated heating station on the base of Siemens RVD", notify 04.07.2018, publ. 08.17.2018.

8. Bobukh, A.A. and Kovalev, D.A. (2012), "Investigation of objects of control of a closed central heating system on their physical models", Energosberezhenie. Energetika. Energoaudit, Vol. 104, no. 10 , pp. 35-40. (in Russian)

9. Draper, N. and Smith, G. (2007), Prikladnoy regressionnyiy analiz [Applied regression analysis], Translated by Vlasenko M., Imamutdinovoy R.G., Orehovoy N.A., Williams Publishing House, Moscow. (in Russian) 
10. Perekrest, A., Chornyi, O., Sivyakova, G. and Gerasimenko, O. (2018), Computerized system of distributed monitoring of parameters of thermal comfort of civil buildings, DIALOG PRINT, Temirtau.
11.G. Geoffrey, Vining, Elizabeth, A. Peck and Douglas, C. (2012), Montgomery. $5^{\text {th }}$ edition, Introduction to Linear Regression Analysis, John Wiley \& Sons.

\section{КОМПЛЕКСНАЯ МОДЕЛЬ АВТОМАТИЗИРОВАННОЙ СИСТЕМЫ УПРАВЛЕНИЯ ТЕПЛОПОТРЕБЛЕНИЕМ МНОГОКВАРТИРНОГО ДОМА}

\section{А. Л. Перекрест, В. В. Ченчевой, Е. О. Чеботарёва}

Кременчугский национальный университет имени Михаила Остроградского

ул. Первомайская, 20, г. Кременчуг, 39600, Украина.

E-mail: pksg13@gmail.com,vladchen.86@gmail.com,yevheniia.ch93@gmail.com

Проведен пассивный многофакторный эксперимент с использованием регрессионного анализа для определения зависимости значения внутренней температуры в представительском помещении многоквартирного дома от температуры теплоносителя в обратном трубопроводе, тепловой мощности системы отопления и температуры окружающей среды. Получена математическая модель, которая комплексно описывает работу системы управления тепловым пунктом. Проверка адекватности модели проведена с помощью коэффициента корреляции Пирсона, коэффициента детерминации, скорректированного коэффициента детерминации, стандартной ошибки уравнения регрессии, коэффициента Стьюдента. Показатели качества подтвердили высокую адекватность полученной модели. Полученные результаты могут использоваться для настройки работы автоматизированных индивидуальных тепловых пунктов многоэтажных жилых домов в виде рекомендаций к значениям обратных температур теплоносителя, обеспечивающих гарантированную экономию тепловой энергии при поддержке нормативных внутренних температур

Ключевые слова: тепловой пункт; регрессионный анализ; пассивный многофакторный эксперимент.

Стаття надійшла 26.11.2018. 